\title{
耐火塗料の耐火性能に及ぼす鉄骨部材の熱容量の効果 EFFECT OF HEAT CAPACITY OF STEEL MEMBERS ON THE FIRE RESISTANCE OF INTUMESCENT COATING
}

\author{
作本好文*1, 山口種 美*2, 岡田忠義*3, 吉田正友*4, 田坂茂樹*5 \\ Yoshifumi, SAKUMOTO, Tanemi YAMAGUCHI, Tadayoshi OKADA, Masatomo YOSHIDA \\ and Shigeki TASAKA
}

\begin{abstract}
As intumescent coating has lower level of insulation than ordinary protective materials, we have already reported that a period of fire resistance not less than one hour was obtained by using Fire Resistant steel which has a higher strength at high temperatures.

As the actual steel sections used for multi-stroy buildings are usually heavier than that of the sections used in standard fire tests, the steel temperature is relatively low because of their heat capacities.

This paper presents experimental results of the heat test of steel members coated by an intumescent coating with various heat capacities. By simulating the measured steel temperatures, design diagrams for determining the coating thickness were obtained.
\end{abstract}

Keywords : fire resistance, coating, steel, high temperature, heat capacity 耐火, 塗料, 鋼材, 高温, 熱容量

\section{1.まえがき}

耐火塗料は，高温時（火災時）に主成分であるポリリ ン酸アンモニウムなどが発泡して断熱性能を発揮する耐 火被覆（以下，被覆）である。発泡前は一般の塗料であ ることから断熱性能はなく，発泡後もロックウールなど と比較して断熱性能が低い被覆であることから，欧州各 国で主として要求耐火時間 30 分・60 分用に使用されて いる。

本研究で使用した耐火塗料はドイツ製（屋内用）で， DIN 4102 に規定する耐火試験により F 30（耐火時間 30 分）の認定を取得した材料である。

筆者らは，この塗料を，一般建築用鋼材 (以下，一般 鋼）と比較して高温強度が高く鋼材温度 $600^{\circ} \mathrm{C}$ におけ る降伏点が常温時降伏点の規格值の $2 / 3$ 以上を有する建 築構造用耐火鋼材" (Fire Resistant Steel : 以下, FR 鋼) で製作した柱・梁に塗布し，載荷加熱試験（以下，既報 の載荷加熱試験）により 1 時間耐火相当の性能が得られ ることを実験的に明らかにしている213)。この研究は， 耐火塗料の断熱性能を FR 鋼で補うことで，長時間の 耐火性能を得ることを目的としたものである。
既報の載荷加熱試験の試験条件（試験体の形状，塗膜 厚および塗布量) および試験結果を表一1に，また，試 験時間と鋼材温度の関係を図一1 (柱), 図一2 (梁) に 点線で示した (参考)。ここで, 耐火時間は, 柱・梁が 長期荷重を支持できなくなった時点（図中の丸印）にお ける試験時間（加熱時間）としている。なお，加熱はそ の時点で中止している。

図一1，2から明らかなように，耐火塗料は鋼材温度 $300^{\circ} \mathrm{C}$ 近辺で発泡を完了し断熱性能を発揮する。した がって，鋼材に一般鋼を使用すると，JIS A 1304 に規 定する許容鋼材温度 (平均 $350^{\circ} \mathrm{C}$ ) を短時間で上回り, 奏用的な耐火時間（例えば 1 時間）が得られない。鋼材 にFR 鍓を使用すると 1 時間耐火相当の性能が得られ るが, 塗膜厚は $1.8 \mathrm{~mm}$ 以上必要となった。本来, 耐火 塗料は，一般の被覆材料と比べて美観に優れていること が利点であるから，塗膜は薄膜であることが望ましい。

一方, 一般に中高層ビルの鉄骨は，JIS A 1304 に規 定する標準試験体 (後述, 既報の載荷加熱試験でも使用) と比べて断面が大きく，熱容嘼の効果で同じ加熱条件で も鋼材温度の上昇が少なく，塗膜厚を軽減する，あるい
*1 新日本製鐵株式会社・工博

*2 新日本製鐵株式会社・工修

*3 新日本製鐵株式会社・工博

*4 日本建築総合試験所·工修

*5 日本建築総合試験所
Nippon Steel Corporation, Dr. Eng. Nippon Steel Corporation, M. Eng. Nippon Steel Corporation, Dr. Eng. Japan Building Research Corporation, M. Eng. Japan Building Research Corporation 
表一1 載荷加熱試験, 認定試験（DIN 4102）の試験条件・試験結果

\begin{tabular}{|c|c|c|c|c|c|c|c|c|c|c|c|c|c|}
\hline \multirow{3}{*}{$\begin{array}{l}\text { 試 } \\
\text { 種 }\end{array}$} & \multirow{3}{*}{$\begin{array}{l}\text { 験 } \\
\text { 別 }\end{array}$} & 試 & \multicolumn{2}{|l|}{ 験 } & \multicolumn{4}{|c|}{ 耐 火 塗 料 仕 様 } & \multicolumn{2}{|c|}{ 試 } & 绘 & 結 & \\
\hline & & \multirow{2}{*}{ 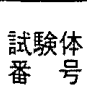 } & \multirow{2}{*}{ 断 面 形 状 } & \multirow{2}{*}{$\begin{array}{l}\mathrm{Hp} / \mathrm{A} \\
\left(\mathrm{m}^{-1}\right)\end{array}$} & \multirow{2}{*}{$\begin{array}{l}\text { 塗膜厚 } \\
(\mathrm{mm})\end{array}$} & \multicolumn{3}{|c|}{ 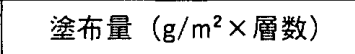 } & \multirow{2}{*}{$\begin{array}{l}\text { 耐 火 } \\
\text { 時 } \\
\text { (分) } \\
\text { (分) }\end{array}$} & \multicolumn{4}{|c|}{ 鋼 材温度 $\left({ }^{\circ} \mathrm{C}\right)$} \\
\hline & & & & & & 錆止層 & 発 泡 層 & 保護層 & & 下フランジ & ウェフ & 上フランシ & 平 均 \\
\hline \multirow{2}{*}{ 載 } & \multirow{2}{*}{ 柱 } & PI48 & $\mathrm{H}-295 \times 301 \times 9.9 \times 14.9$ & 153 & 2.58 & 150 & $1600 \times 3$ & 200 & 76 & - & - & - & 675 \\
\hline & & PI36 & $\mathrm{H}-299 \times 299 \times 9.9 \times 14.9$ & 153 & 2.33 & 150 & $1200 \times 3$ & 200 & 79 & - & - & - & 683 \\
\hline \multirow{2}{*}{$\begin{array}{l}\text { 荷 } \\
\text { 加 }\end{array}$} & \multirow{5}{*}{ 梁 } & PI36A & $\mathrm{H}-399 \times 201 \times 7.9 \times 12.0$ & 177 & 1.80 & 150 & $1100+1300+1200$ & 200 & 61 & 675 & 666 & 671 & 671 \\
\hline & & PI30A & $\mathrm{H}-399 \times 201 \times 7.9 \times 12.0$ & 177 & 1.85 & 150 & $1000 \times 3$ & 200 & 60 & 702 & 688 & 654 & 681 \\
\hline \multirow{3}{*}{$\begin{array}{l}\text { 試 } \\
\text { 験 }\end{array}$} & & PI48A & $\mathrm{H}-400 \times 201 \times 7.9 \times 12.5$ & 173 & 2.92 & 150 & $1600 \times 3$ & 200 & 70 & 683 & 676 & 608 & 656 \\
\hline & & PI42B & $\mathrm{H}-400 \times 200 \times 7.9 \times 11.8$ & 179 & 2.42 & 150 & $1400 \times 3$ & 200 & 65 & 745 & 728 & 711 & 728 \\
\hline & & PI36B & $\mathrm{H}-400 \times 200 \times 8.6 \times 13.2$ & 168 & 2.35 & 150 & $1300 \times 3$ & 200 & 74 & 624 & 636 & 606 & 622 \\
\hline \multirow{2}{*}{$\begin{array}{l}\text { DIN } \\
4102\end{array}$} & 柱 & \multicolumn{2}{|r|}{ - } & $\leqq 160$ & 0.70 & 200 & 950 & 200 & 30 & \multicolumn{4}{|c|}{-} \\
\hline & 梁 & \multicolumn{2}{|r|}{-} & $\leqq 200$ & 0.90 & 200 & $650 \times 2$ & 200 & 30 & \multicolumn{4}{|c|}{ - } \\
\hline
\end{tabular}

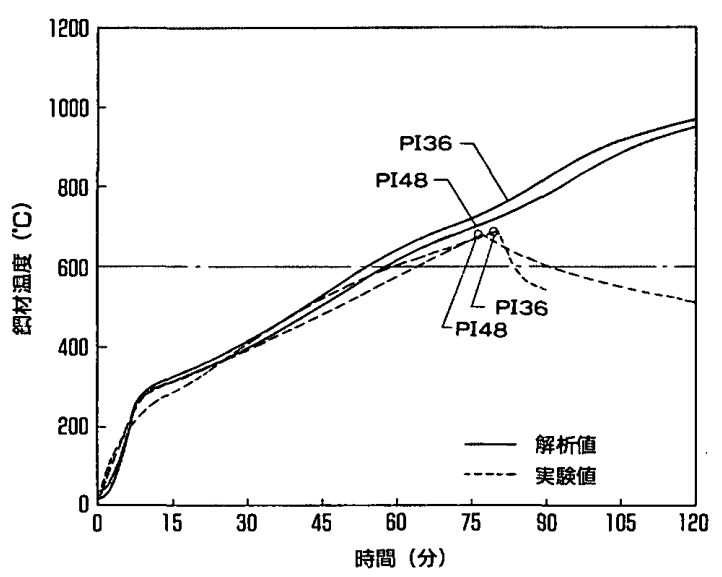

図一1 試験時問と鋼材温度の関係（柱載荷加熱試験，試験およ び解析)

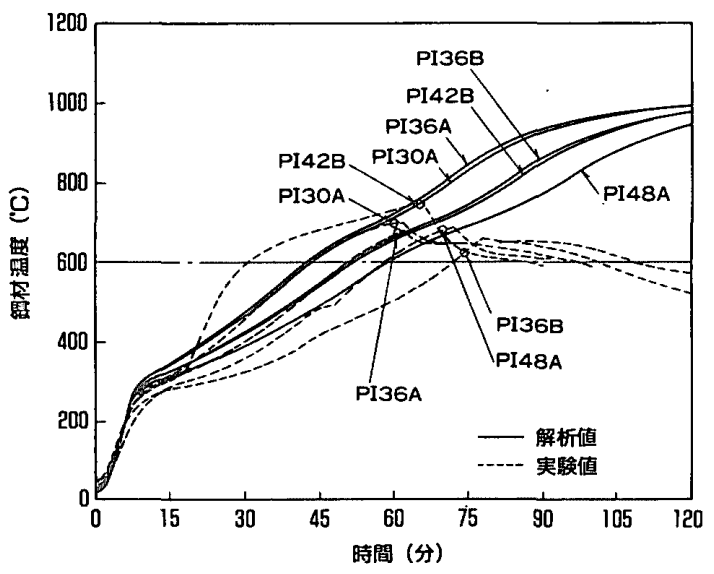

図一2 試験時間と鋼材温度の関係（梁載荷加熱試験，試験およ び解析)

は同じ塗膜厚で耐火時間を伸ばすことができる。

本研究は，耐火塗料の耐火性能に及ぼす鉄骨部材の熱 容量の効果を加熱試験（以下，熱容量試験）により実験 的に明らかにしたものである4”。また，熱容量試験およ び既報の載荷加熱試験における鋼材温度の測定值を一次 元差分熱伝導解析 ${ }^{5}$ によりシミュレートすることで, 熱
容量をパラメーターとした設計用の鋼材温度算定図を作 成した。

なお，このような研究は，欧州では，すでにBS 476 なよ゙で耐火材料の指定の条件として採用されているが， 我が国では，ロックウールなどの一般的な被覆材料に関 する研究(例 ${ }^{6}$ はあるものの, 耐火塗料に関するものはな い。

\section{2. 熱容量試験}

\section{1 試験体}

JIS A 1304 では耐火試験における試験体の大きさを, 柱：断面積 $120 \mathrm{~cm}^{2}$ 以下, 1 辺約 $30 \mathrm{~cm}$

梁：断面積 $100 \mathrm{~cm}^{2}$ 以下，せい約 $40 \mathrm{~cm}$ と規定しており，標準試験体として，

柱: $\mathrm{H}-300 \times 300 \times 10 \times 15\left(\mathrm{Hp} / \mathrm{A}=146.0 \mathrm{~m}^{-1}\right)$

梁: H-400×200× $8 \times 13\left(\mathrm{Hp} / \mathrm{A}=161.2 \mathrm{~m}^{-1}\right)$

が使用されている。ここで，

$\mathrm{Hp} / \mathrm{A}$ : 断面係数 $\left(\mathrm{m}^{-1}\right)$,

$\mathrm{Hp}$ : 断面周長 $(\mathrm{m}), \mathrm{A}$ ：断面積 $\left(\mathrm{m}^{2}\right)$

である。断面係数は，加熱面積 (断面周長) と断面積と の比率で熱容量の指標となる。なお，梁は 3 面加熱（上 フランジ側に床があり加熱されない）を想定しており， 断面周長にはフランジ上面を含んでいない。

試験体の形状および寸法を表一2，図一3〜 5 に示す。 試験体は, 中高層ビルの鉄骨を想定した, 箱形断面, $\mathrm{H}$ 形断面および中実丸棒の 3 種類である。熱容量は，箱形 断面および $\mathrm{H}$ 形断面では板厚を，中実丸棒では直径を変 化させることで設定した。

箱形断面は柱を想定したもので，板厚は最小 $9 \mathrm{~mm}$ か ら最大 $90 \mathrm{~mm}$ までの 4 種類とした。箱形断面は閉鎖断 面 (内部が中空) であることから，断面積と比べて周長 が小さく熱容量が大きい。

$\mathrm{H}$ 形断面は梁を想定したもので，試験体は，標準試験 
表一2 熱容量試験（試験条件および試験結果）

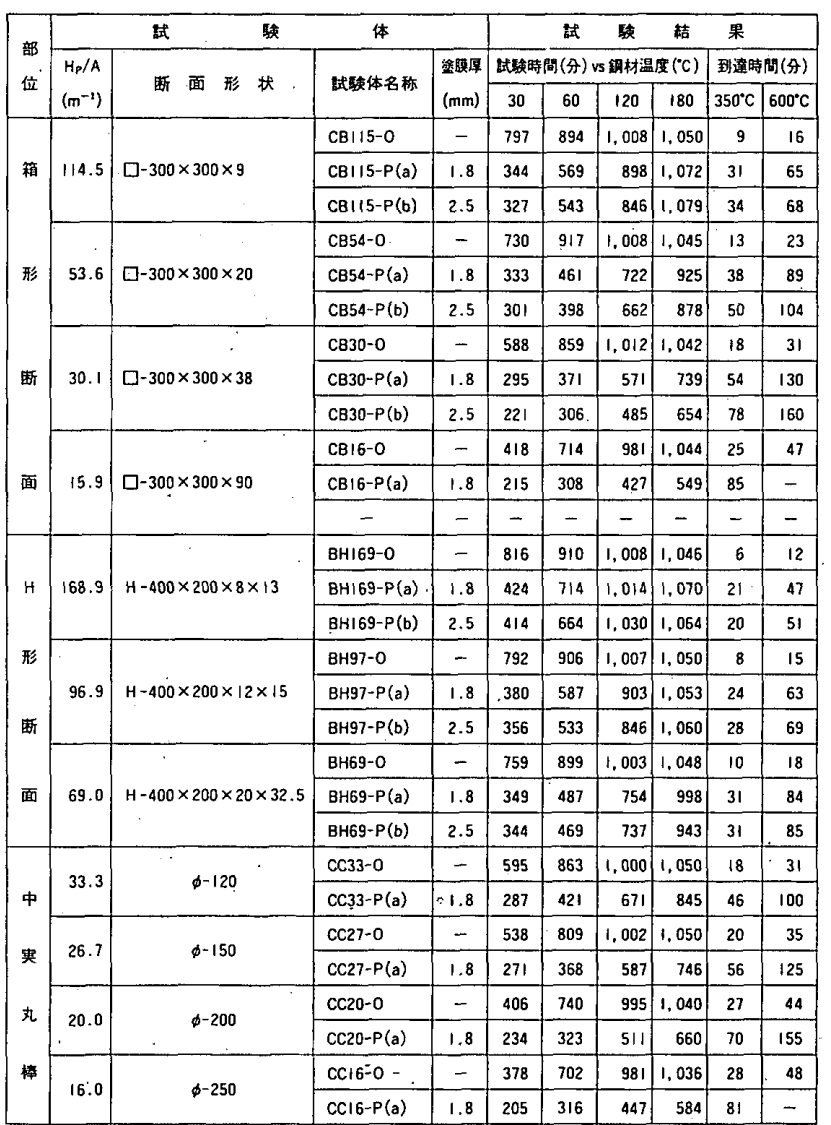

体からロール H形鋼のほぼ最大板厚に相当するサイズま での 3 種類とした。

中実丸棒はブレースや柱を想定したもので，最大径は 丸棒のほぼロール可能なサイズまでとした。

\section{2 耐火塗料}

本研究で使用した耐火塗料は，錆止層・発泡層・保護 層から構成されている。塗膜厚および塗布量は，既報の 載荷加熱試験（表一1）を参考に設定した。すなわち, 標準試験体でほぼ 1 時間耐火相当の性能が得られる塗膜 厚 $1.8 \mathrm{~mm}$ （発泡層塗布量：1200 $\mathrm{g} / \mathrm{m}^{2} \times 3$ 層）を規準と し,さらに長時間の耐火性能を得る目的で塗膜厚 2.5 $\mathrm{mm}$ (発泡層塗布量: $1700 \mathrm{~g} / \mathrm{m}^{2} \times 3$ 層) の試験体を追加 した。塗膜が厚くなると発泡厚も大きくなり加熱中に脱 落するおそれがあることから，2.5 mm はほぼ限界の厚 さと考えられる。なお，熱容量の大きな試験体では塗膜 厚 $2.5 \mathrm{~mm}$ は省略した。

錆止層・保護層の塗布量は, 各塗膜厚とも既報の載荷 加熱試験の試験体と同じとした（表一1）。

なおここで設定した塗膜厚は，DIN 4102 の認定試 験における塗膜厚（表一 $1 ; 1.0 \mathrm{~mm}$ 以下）と比べてか なり厚くなっている。これは, DIN 4102 の認定条件が, 耐火時間 30 分 (F 30)であることが主たる要因であるが, 鋼種 (一般鋼) や耐火時間の判定規準の違い(一般鋼で も載荷加熱試験が実施され，加熱試験で評価する場合も
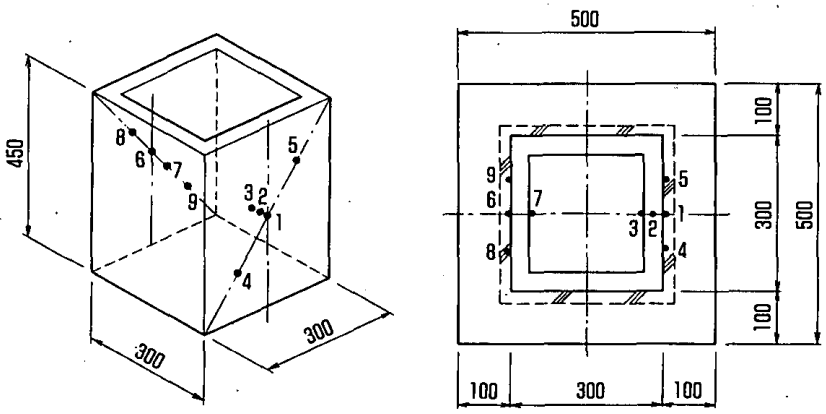

図一3 熱容量試験の試験体の形状および寸法（箱形断面）
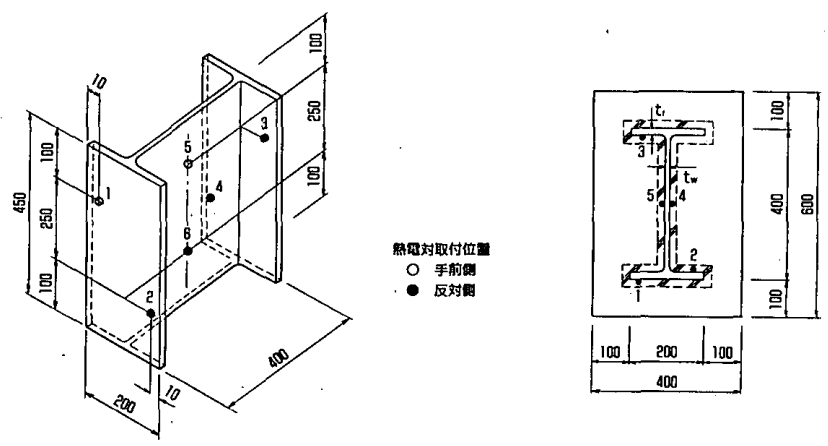

図一4 熱容量試験の試験体の形状および寸法（H 形断面）
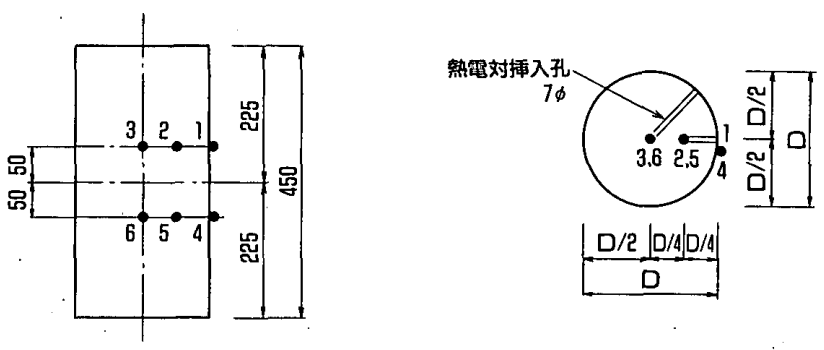

図一5 熱容量試験の試験体の形状および寸法（中実丸棒）

許容鋼材温度は $500^{\circ} \mathrm{C}$ ). から, 本研究で設定した塗膜厚 と単純に此較することは困難である。

\section{3 試験条件}

試験条件を表一2に示す。試験体数は，断面形状, 熱 容量, 耐火塗料の有無および塗膜厚をパラメーターとし た28体である。

\section{4 試験方法}

試験は, JIS A 1304 に規定する標準加熱曲線に準拠 した 3 時間加熱とした。鋼材温度は $\mathrm{K}$ 熱電対を用いて测 定した。測定位置を図一3〜 5 に示す。

写真一1 - 3 に, 箱形断面 (CB 115-P (a)), H 形断面 (BH 169-P (a)) および中実丸棒 (CC 20-P (a)) 用試 験体の外観を示す。試験体には上下面にセラミックボー ド $(400 \times 400$, 厚さ $50 \mathrm{~mm})$ を耐火接着材により接着 して，上下面からの入熱を防止した。また，H形断面試 験体は梁を想定したことから，3面加熱とするためフラ ンジの片側にもセラミックボードを装着した。

\section{5 試験結果}

写真一 4 6 に, 箱形断面 (CB 115-P (a)), H 形断面 


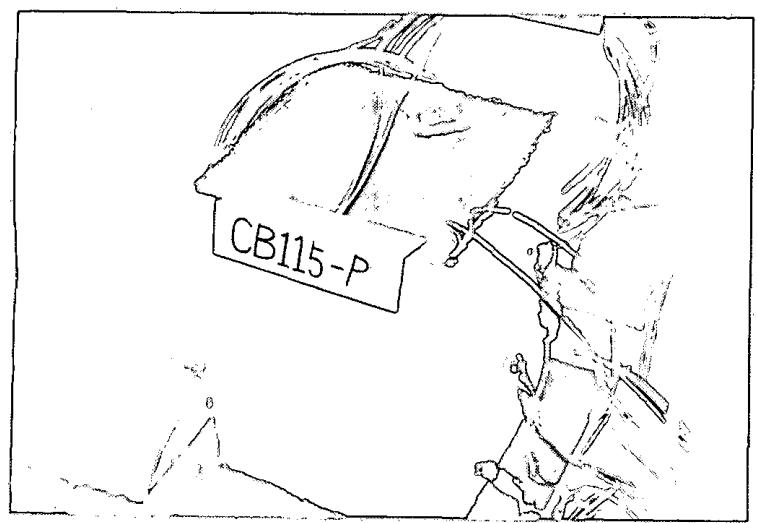

写真一1 熱容量試験の試験体 (CB 115-P (a)：試験前)

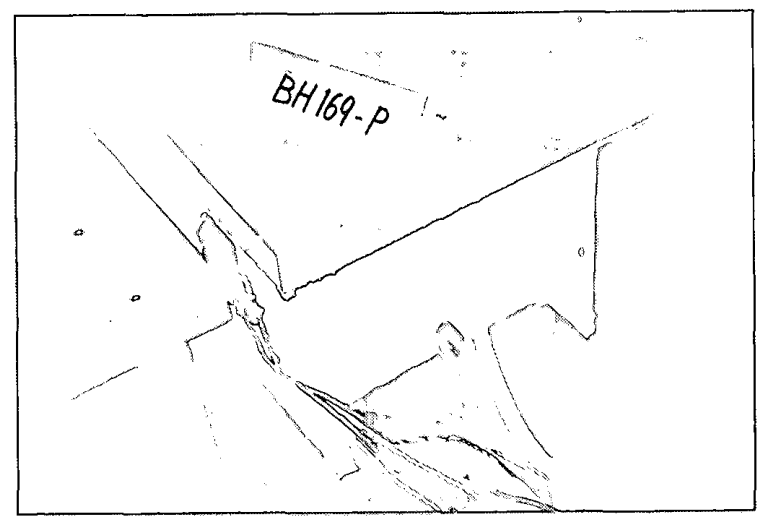

写真一2 熱容量試験の試験体（BH 169-P(a)：試験前）

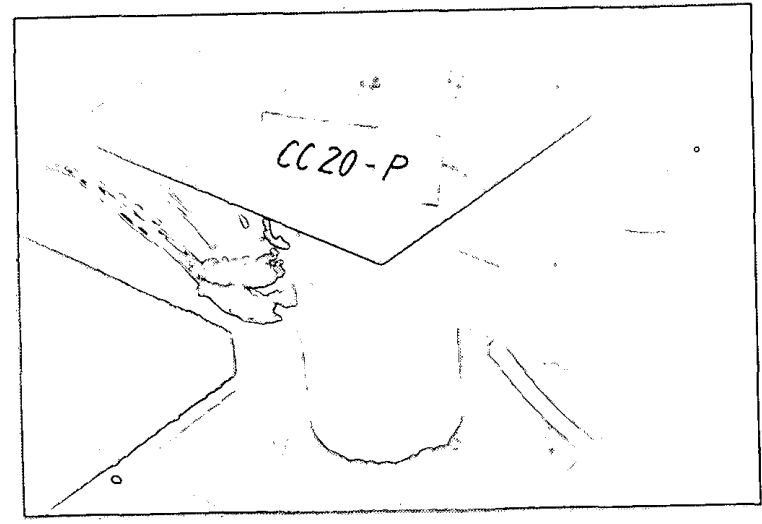

写真一3 熱容量試験の試験体 (CC 20-P (a) : 試験前)

(BH 169-P (a)) および中実丸棒 (CC 20-P (a)) 用試 験体の試験後の外観を示す。

また，表一 2 および図一6〜8に，各試験体の鋼材温度 （平均值）の測定結果を示す。また, 表一2では, 試験 時間 30 分, 60 分, 120 分, 180 分における鋼材温度と, 鋼材温度が $600^{\circ} \mathrm{C}$ に達した試験時間（FR 鋼を想定）を 示した。なお，一般鋼の許容鋼材温度である $350^{\circ} \mathrm{C} に$ 達した試験時間も参考に示した。

無被覆の試験体では鋼材温度の上昇が著しく，熱容量 の最も大きな試験体 $\mathrm{CB} 16-\mathrm{O}, \mathrm{CC}$ 16-O でも, 試験時 間 60 分における鋼材温度は $714^{\circ} \mathrm{C}, 702^{\circ} \mathrm{C}$ な゙といず れも $600^{\circ} \mathrm{C}$ を大きく上回った。以上の結果から, 標準 加熱曲線に準拠した加熱を受けると, 熱容量の効果が加

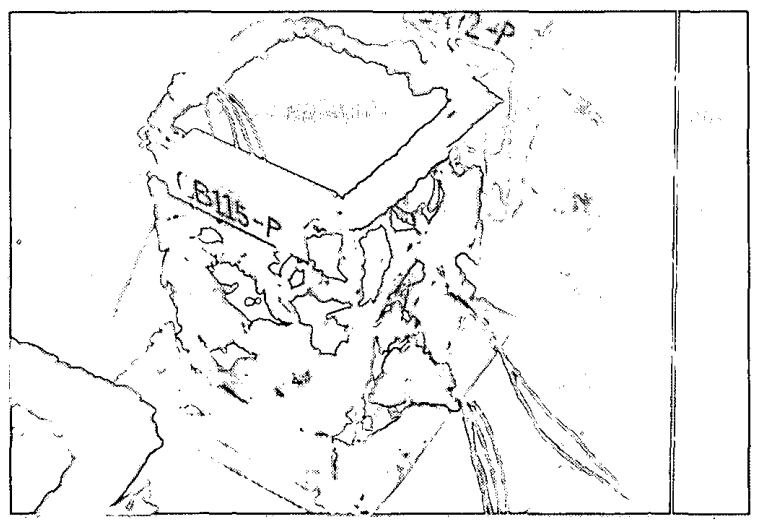

写真一4 熱容量試験の試験体 (CB 115-P (a)：試䀫後)

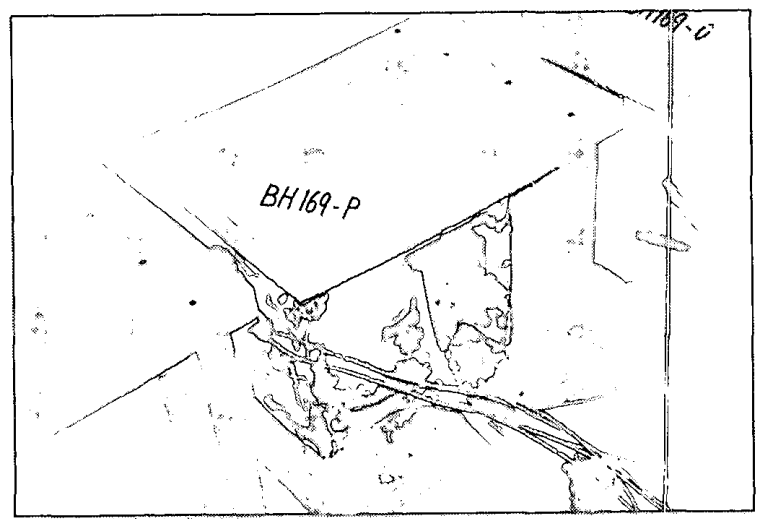

写真一5 熱容量試験の試験体（BH 169-P(a)：試験後)

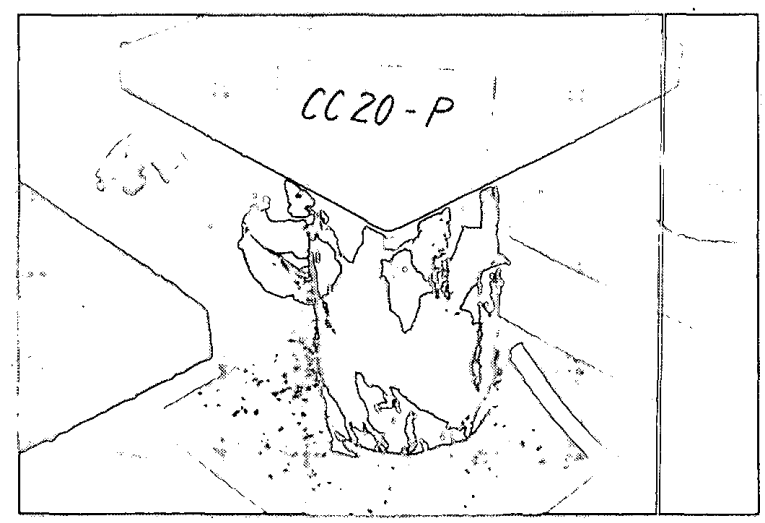

写真一6 熱容舅試験の試験体 (CC 20-P (a) : 試験後)

わっても無被覆では 1 時間耐火相当の性能は得られな かった。熱容量の効果は耐火塗料の試験体ほよ゙顛著では ないが，熱容量の大きな試験体（箱形断面，中実丸棒） では鋼材温度に明らかな差が得られた。

耐火塗料の試験体では, 既報の載荷加熱試験と同様, 耐火塗料が鋼材温度 $300^{\circ} \mathrm{C}$ 近辺で発泡を完了し断熱性 能を発揮しており，無被覆の試験体と比べて鋼材温度の 上昇速度が遅くなっている。熱容量の効果は無被覆の試 験体と比べて明らかで, 筀膜厚 $1.8 \mathrm{~mm}$ および $2.5 \mathrm{~mm}$ の試験体とも熱容量ごとに鋼材温度の上昇速度に大きな 差が得られた。

塗膜厚 $1.8 \mathrm{~mm}$ の試験体では, $\mathrm{BH}$ 169-P(a) を除い て試験時間 60 分における鋼材温度は $600^{\circ} \mathrm{C}$ 以下となっ 
た。また，熱容量の大きい武験体 CB 30-P (a)， CB 16-P (a), CC 27-P (a), CC 20-P (a), CC 16-P(a) で は, 試験時間 120 分でも鋼材温度は $600^{\circ} \mathrm{C}$ 以下となっ た。

また，塗膜厚 $2.5 \mathrm{~mm}$ の試験体ではさらに鋼材温度の 上昇速度は遅くなり, 塗膜厚 $1.8 \mathrm{~mm}$ の試験体と比べて, 例えば，箱形断面では試験時間 60 分における鋼材温度 が $26 \sim 65^{\circ} \mathrm{C}$, 試験時間 120 分では $52 \sim 86^{\circ} \mathrm{C}$ 低くなった。

以上の結果から,

(1) 耐火塗料の試験体では熱容量の効果は明らかで, 熱

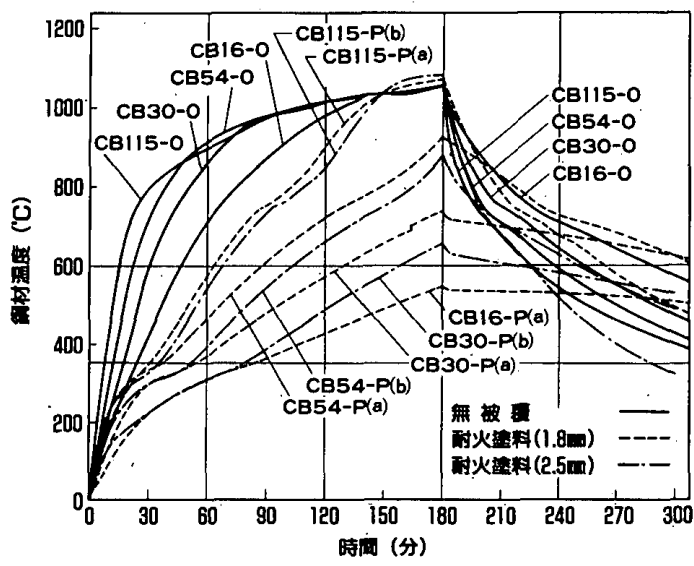

図一6＼cjkstart試験時間之龬材温度の関係·(箱形断面)

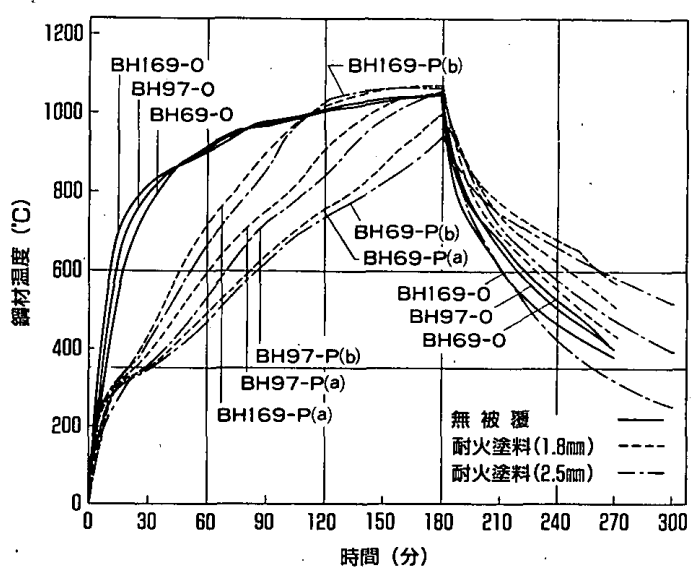

図一7 試験時間と鋼材温度の関係（H形断面）

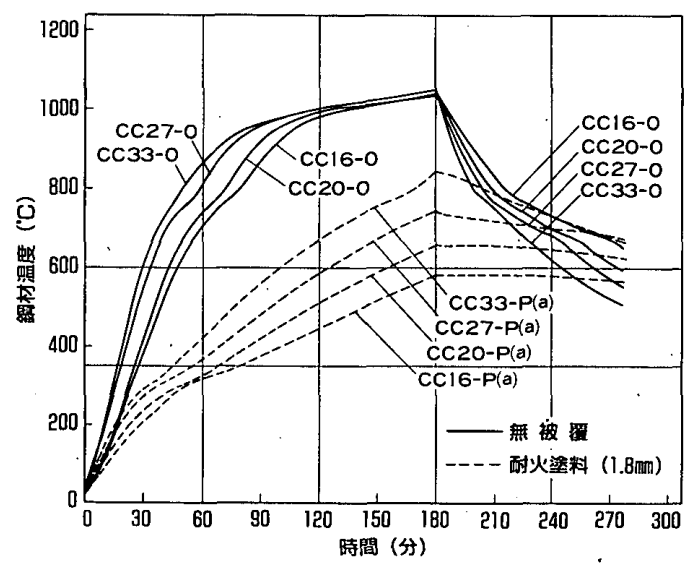

図一8 試験時間と鋼材温度の関係 (中実丸棒)
容量ごとに鋼材温度の上昇速度に大きな差が得られた。 (2) 熱容量が大きい試験体では，鋼材温度が $600^{\circ} \mathrm{C} に$ 達する試験時間が 2 時間を超え, 既報の載荷加熱試験で 得られた標準試験体における耐火時間を大幅に伸ばすこ とができた。

\section{3. 熱伝導解析}

熱容量試験で得られた試験時間と鋼材温度との関係を 一次元差分熱伝導解析によりシミュレートした。この手 法は，一次元要素でモデル化された熱伝導方程式を時間 軸方向に step by step で解析するもので, 時刻歴で変化 する雾囲気温度からモデルの始端および終端に設定した 熱伝導境界面を通して流入・流出する熱量に対して, 各 要素の温度を時刻歴で求めることができる。また，その 特徴は,

(1) 熱伝導率・比熱の温度依存性

(2) 被覆材内の水分の蒸発潜熱

(3) モデルの軸方向の断面積変化

が考慮できることである。モデルの軸方向の断面積の変 化が考慮できることから，本来二次元で取り扱うべき鉄 骨被覆部材のモデルを，図一9に示すように近似的に一 次元に置換することができる。

解析手法は文献5)同じで，非定常熱伝導方程式は式

(1) で与えている。

$$
[M]\{d \phi / \mathrm{d} t\}=[K] \mid \phi\}+\{F\}
$$

ここで,

$\left\{\phi \mid\right.$ : 節点温度ベクトル $\left({ }^{\circ} \mathrm{C}\right)$

$[M]$ : 熱容罢マトリックス

$[K]$ : 熱伝導マトリックス

$\{F\}$ : 熱流束ベクトル

解析で採用した各熱定数を以下に示す。

(1) 密 度: $1800 \mathrm{~kg} / \mathrm{m}^{3}$
試験体
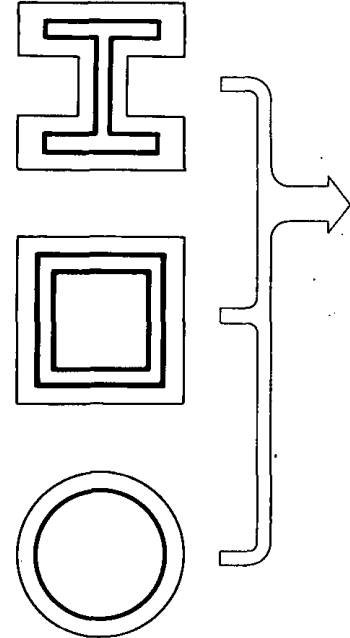

解析モテル

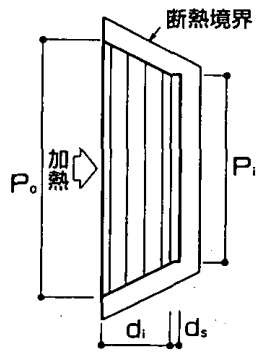

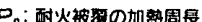

$P_{i}$ : 酎火被㱟の内表面周長

$d_{i}:$ 的火贫要の西さ

$d_{2}:$ 鉄骨の等価原さ $\left(H / P_{1}\right)$

：料骨の断面相
図一9鉄骨被覆部材の熱伝導解析のモデル化 


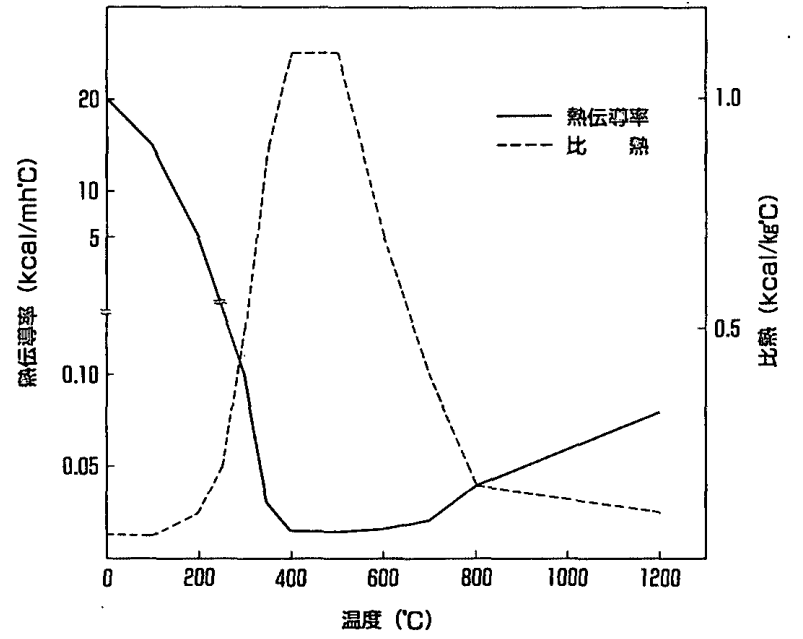

图一10 比熱・熱伝導率の温度依存性の仮定（解析用）

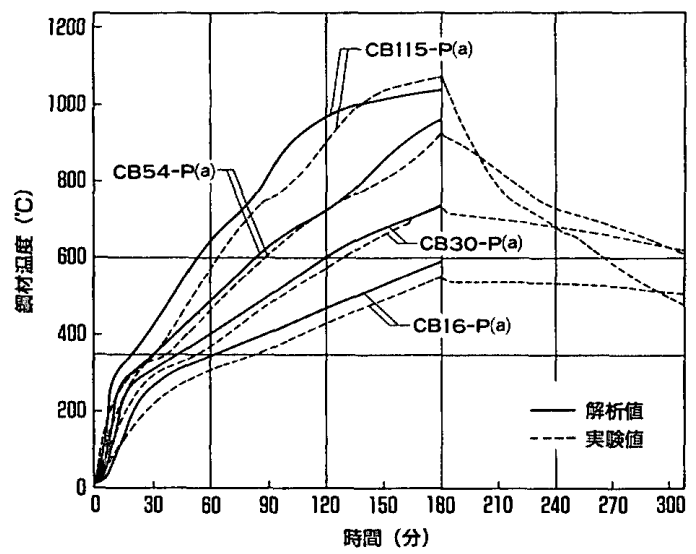

図一11 鋼材測定值と解析值の比較（箱形断面：塗膜厚 1.8 $\mathrm{mm}$ )

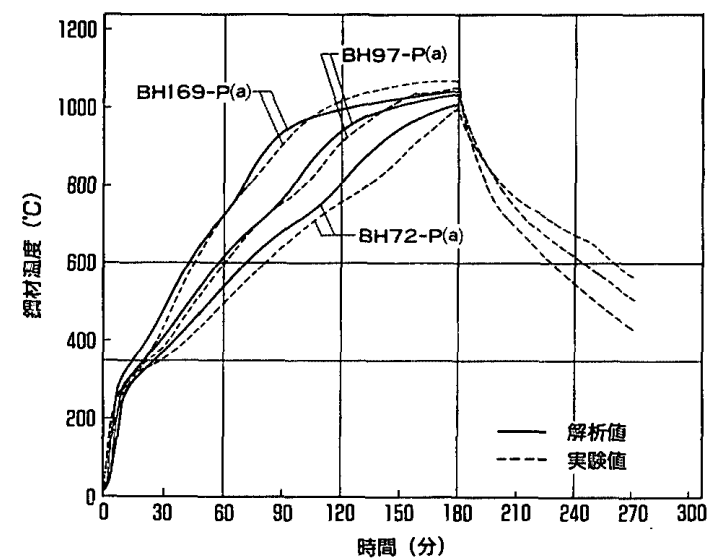

図-12銅材測定値己解析値の比較 ( $\mathrm{H}$ 形断面：塗膜厚 1.8 $\mathrm{mm}$ )

(2) 熱伝導率 : 図-10

(3) 比 熱：図-10

(4) 含 水率: 0.0

耐火狳料は，一般の被覆材料と異なり発泡によって熱 伝導率および比熱が不連続となる。本研究は熱定数その ものの測定を目的としていないことから，熱伝導率およ び比熱の温度依存性（図一10）は，解析により測定值を

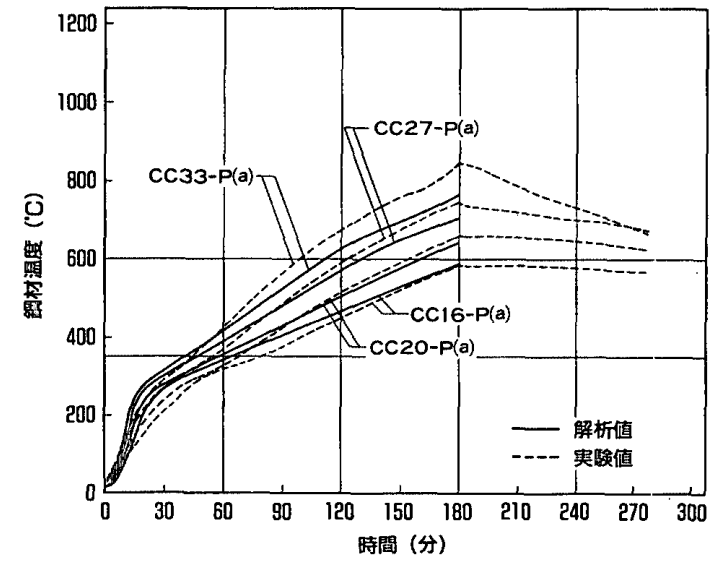

図一13 鋼材測定値と解析值の比較（中実丸棒：塗膜厚 1.8 $\mathrm{mm}$ )

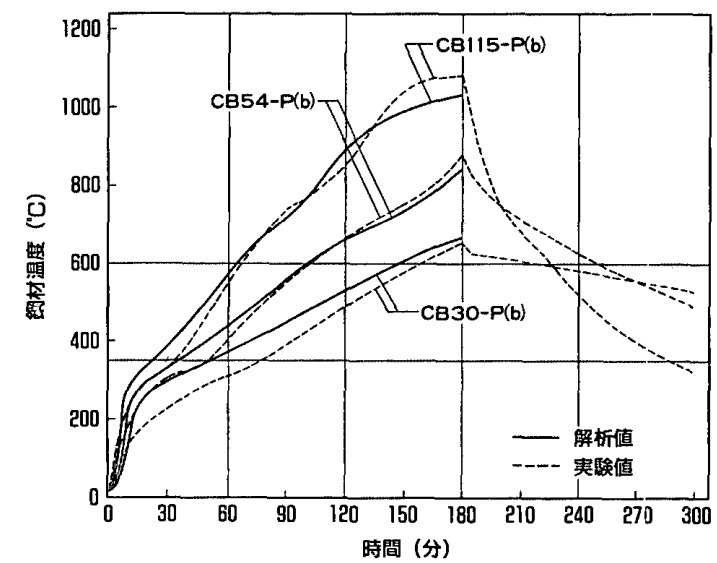

図-14 鋼材測定值と解析値の比較（箱形断面：梁膜厚 2.5 $\mathrm{mm}$ )

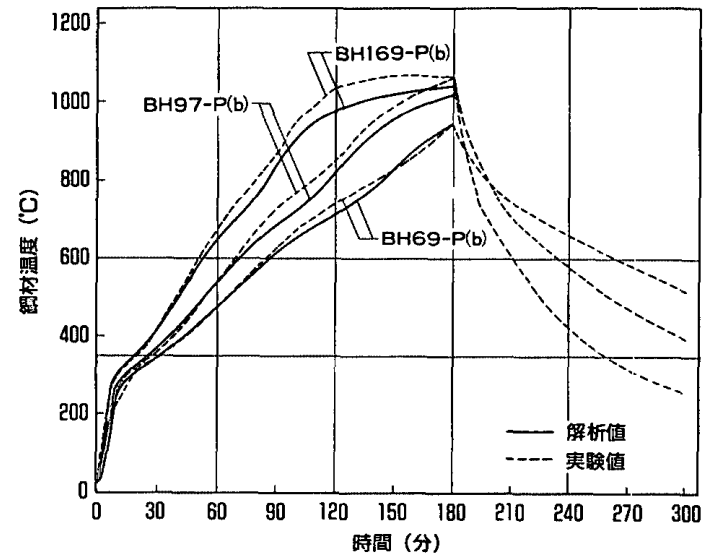

図一15 鋼材測定値と解析値の比較 ( $\mathrm{H}$ 形断面：涂膜厚 2.5 $\mathrm{mm}$ )

近似できるよう仅定したものである。

熱伝導率は，発泡前は一般の塗料程度，発泡後はロッ クウールなよ゙より多少小さい值とし，また，比熱は耐火 塗料の発泡温度近辺で大きな值を設定した。耐火塗料は 発泡時に炭酸ガス，アンモニア，水蒸気なよ゙のガスを発 生することから，本来，蒸発潜熱の影響を考虑する必要 があるが，ガスの発生温度や吸熱量の測定は困難であり 
本解析では考慮していない。したがって，比熱は，この 発生ガスの蒸発潜熱の影響も含めた仮定となっている。 なお，塗膜厚は発泡後も発泡前と同じとした。

図一11 15に，鋼材温度の测定值と解析值との比較 を示す。解析は試験時間 180 分までとし, 冷却域は対象 外とした。解析值は, 発泡による鋼材温度上昇の変化も 含めて測定值を極めて良く近似している。また，各断面 形状，塗膜厚の試験体とも熱容量による鋼材温度の差を 良く近似している。

また，既報の載荷加熱試験における鋼材温度の測定值 についても，同様に解析値との比較を行った。解析結果 を図一 1,2 に象線で示す。熱容量試験では，塗膜厚を一 定 $(1.8 \mathrm{~mm}, 2.5 \mathrm{~mm})$ とし試験体の熱容量を変化させ たが，載荷加熱試験では，試験体は標準試験体で熱容量 がほぼ等しいが塗膜厚が異なっている。

柱の試験体は 2 体とも塗膜厚がほぼ同じであることか ら，測定値と解析値とも試験体による差は少ない。解析 値は測定値を良く近似している。

梁の試験体は塗膜厚が異なることから，鋼材温度は測 定値および解析值とも試験体によって差が生じている。 解析値はおおむね测定值と一致しているが, 試験体 PI 42 B では解析值が測定値より低くなっている。これは, 加熱中に発泡層の一部が脱落し鋼材温度が高くなったこ とによると考えられる。

以上，熱容量試験と既報の載荷加熱試験における試験 時間と鋼材温度の関係を一次元差分熱伝導解析によりシ ミュレートすることで, 発泡による鋼材温度上昇の変化 も含めて，熱容量ごとの鋼材温度の測定值を精度良く近 似できることが明らかとなった。また，解析手法や熱定 数の温度依存性の仮定がおおむね妥当であることが検証 できた。

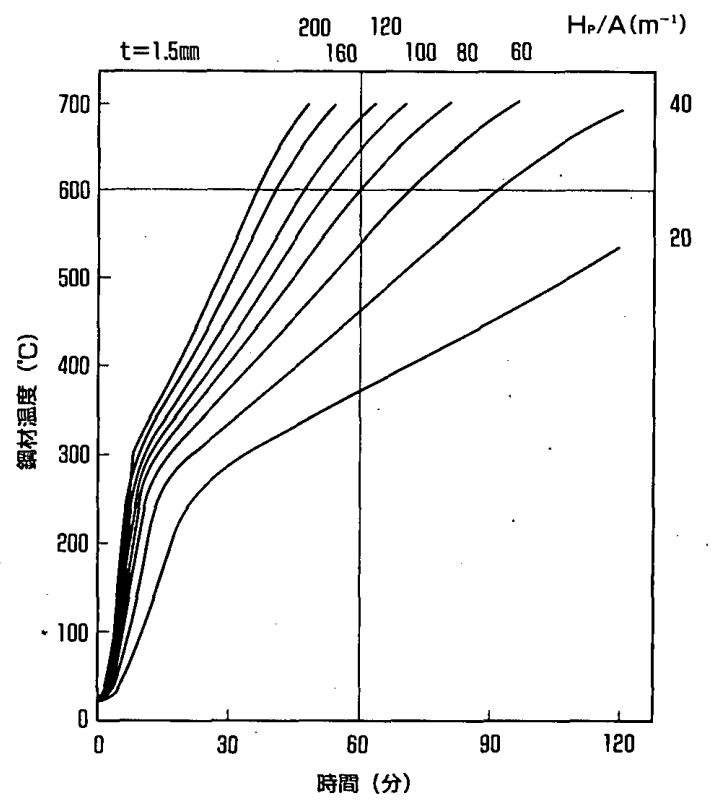

図一16 設計用鋼材温度算定図 (塗膜厚 $1.5 \mathrm{~mm}$ )

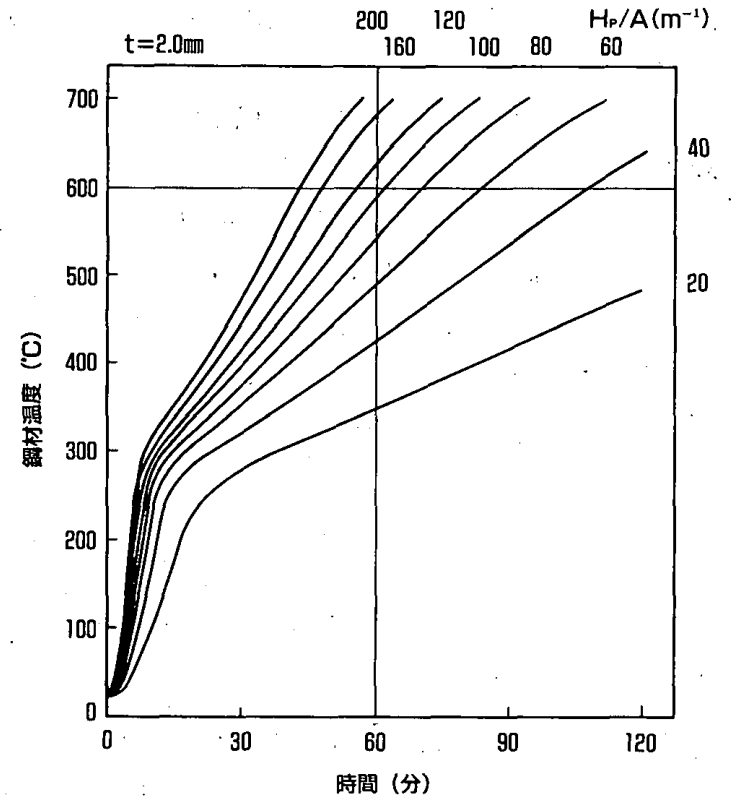

図一17 設計用鋼材温度算定図 (塗膜厚 $2.0 \mathrm{~mm}$ )

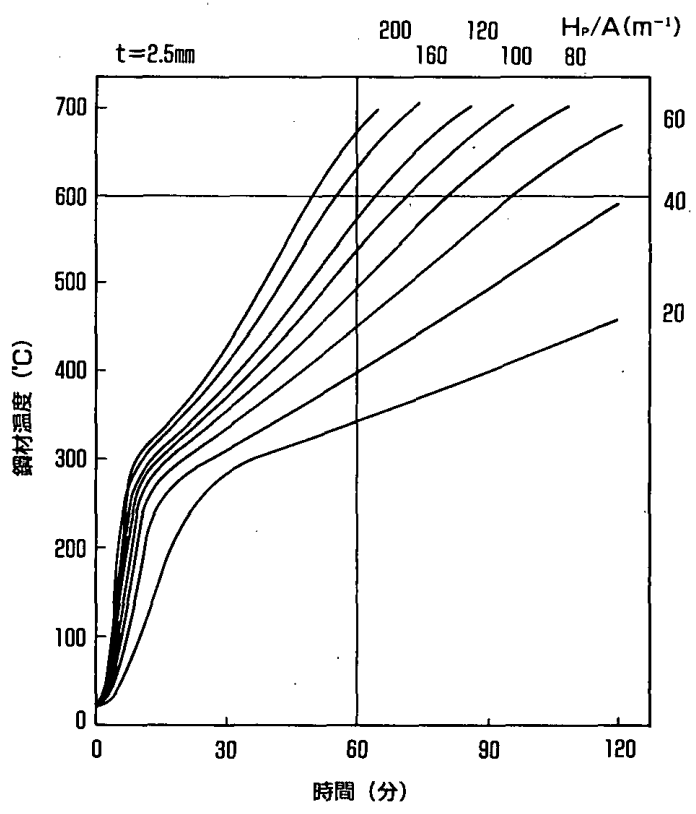

図一18 設計用鋼材温度算定図（塗膜厚 $2.5 \mathrm{~mm}$ )

\section{4. 設計用鋼材温度算定図}

以上の結果から，代表的な塗膜厚について熱容量 $(\mathrm{Hp} / \mathrm{A})$ をパラメーターとした設計用の鋼材温度算定 図を，一次元差分熱伝導解析により作成した（図一16〜 18)。これらの図を使用することで，鉄骨の設計断面か ら熱容量を考慮した最適な塗膜厚を設定することができ る。

\section{5. まとめ}

以上，本研究では，耐火塗料の耐火性能に及ぼす鉄骨 部材の熱容量の効果を加熱試験により実験的に明らかに した。まだ，本試験および既報の載荷加熱試験における 試験時間と鋼材温度の関係を一次元差分熱伝導解析によ 
りシミュレートすることで，設計用の鋼材温度算定図を 作成した。

以上の試験および解析により，以下の点が明らかと なった。

(1) 耐火塗料の試験体では熱容量の効果は明らかで, 熱 容量ごとに鋼材温度の上昇速度に大きな差が得られた。 (2) 熱容量が大きい試験体では，鋼材温度が $600^{\circ} \mathrm{C}$ に 達する試験時間が 2 時間を超え，既報の載荷加熱試験で 得られた標準試験体における耐火時間を大幅に伸ぱすこ とができた。

(3) 熱伝導率，比熱の温度依存性を仮定し，一次元差分 熱伝導解析を行うことで，発泡による鋼材温度上昇の変 化も含めて，熱容量ごとに，鋼材温度の測定值を精度良 く近似できる。

以上の実験および解析の結果から，代表的な塗膜厚に ついて，熱容量をパラメーターとした設計用の鋼材温度 の算定図を作成した。これを使用することで，鉄骨の設 計断面から熱容量を考虑した最適な塗膜厚が設定でき る。

\section{謝辞}

本研究の遂行にご協力いただいた建材試験センターの 斎藤勇造氏, 西田一郎氏, 新日鐵化学の原 基氏に謝意
を表します。

\section{参考文献}

1）作本好文, 大橋 守, 計良光一郎, 斎藤 光: 建築構造 用耐火鋼材の高温強度特性, 日本建築学会墖文報告集, 第 427 号, pp. 107 115，1991.9

2）作本好文，山口種美，岡田忠義，吉田正友，田坂茂樹， 斎藤 光：建築構造用耐火鋼柱の䩂火性能に関する実験 的研究, 日本建築学会論文報告集, 第 434 号, pp. 149 $158,1992.4$

3）作本好文, 山口種美, 岡田忠義, 斎藤勇造, 西田一郎, 斎藤 光：建築構造用耐火鋼梁の耐火性能に関する実験 的研究, 日本建築学会論文報告集, 第 442 号, pp. 147 $156,1992.12$

4) 作本好文, 山口種美, 岡田忠義, 吉田正友, 田坂茂樹: 耐火塗料で被覆した耐火鎆柱の耐火性能, GBRC, pp. 21 -26, Vol. 17, No. 4, 1992.

5）建築物の総合防火設計法，（財）国土開発センター，(財) 日本建築センター

6）茂木 武：耐火試験結果に基づく耐火性能予測法，その 1 回帰伝熱量モデル，その 2 耐火被覆材料 R.W への 回帰伝熱量モデルの適用，日本建築学会関東支部研究報 告集, pp. $261 \sim 268,1989$

(1992 年 12 月 7 日原稿受理, 1993 年 8 月 17 日採用決定) 